The International Journal of Indian Psychology: Volume: 01 | Issue: 04 No. 2 | ISSN 2348-5396

\title{
Job Satisfaction and Organizational Commitment among Public and Private Engineers
}

\author{
Deepak Bhardwaj*, Shilpa Chouhan**, Subhash Meena***
}

\begin{abstract}
The present study is aimed at exploring the job satisfaction and organizational commitment among engineers of government and private organizations. Sample of the study consisted of 25 government engineers and 25 private engineers belong to Jodhpur District. All the employees have been in the age range of 30 to 45 years with service experience ranges between 5 to 15 years and may be of both the services and working in government and private sectors. For this purpose Job Descriptive Index (Smith, Kendall and Hulin, 1969) adopted for Indian settings by Sayeed and Sinha (1981) and further translated in Hindi (by the standard two-time process) and successfully used on a sample other than industrial organizations (Sinha, 1993) and Organization commitment scale developed by Puja Gupta, (2003) was used. Results indicated there is significant difference between engineers of government and private organizations on job satisfaction and organizational commitment.
\end{abstract}

Keywords: Job satisfaction, organizational commitment, engineers, organizations

\section{INTRODUCTION}

Job satisfaction regards one's feelings or state-of-mind regarding the nature of their work. It can be influenced by a variety of factors, e.g., the quality of one's relationship with their supervisor, the quality of the physical environment in which they work, degree of fulfillment in their work, etc.

\footnotetext{
*Research Scholar (deepakbhardwaj32@gmail.com),

**Research Scholar (shilpachouhan15@gmail.com),

***Research Scholar (sbhshmeena@yahoo.com), Department of Psychology, Jai Narain Vyas University, Jodhpur.

(C) 2014 www.ijip.in $\quad$ July-September $2014 \quad 109 \mid \mathrm{P}$ a g e
} 
The International Journal of Indian Psychology: Volume: 01 | Issue: 04 No. 2 | ISSN 2348-5396

A person's job satisfaction is also influenced by what kind of adjustment and interaction one experience in the work setting. Adjustment can be defined as the effective adaption of any individual to his environment both internal and external, including conformity to groups norms, means deals value and so on. Anyone who has ever held a job knows that if he does not get along with his co-workers, the job is unsatisfactory. It has been found that there is also a positive correlation between job satisfaction and adjustment to people on the outside also effects a person's adjustment to his job.

The job satisfaction must begin with an identification of its epistemological roots. Since satisfaction is an emotional response the meaning of the concept can only be discovered and grasped by a process of introspection, that is, an act of conceptual identification directed to one's mental contents and processes. Job satisfaction may be defined (for the present) as a pleasurable or positive emotional state resulting from the appraisal of one's job or experience.

Job satisfaction has been defined as a general attitude toward one's job. It is in regard to one's feelings or state-of-mind regarding the nature of their work. According to Robbins (1997), Job satisfaction is the difference between the amount of rewards employees receive and the amount they believe they should receive. Again Mobey and Locke (1970) opined Job satisfaction and dissatisfaction are function of the perceived relationship between what one expects and obtains from one's job and how much importance or value one attributes to it. Job satisfaction represents a combination of positive or negative feelings that workers have towards their work. Meanwhile, when a worker employed in a business organization, brings with it the needs, desires and experiences which determinates expectations that he has dismissed. Job satisfaction represents the extent to which expectations are and match the real awards.

\section{Impact of job satisfaction}

Job satisfaction has a positive impact on productivity, presence and performance. Satisfaction workers like to perform more willingly and happily, which increases the productivity. Job satisfaction induces employees to remain with the organization. The behaviour of an employee is improved when he works with satisfaction. Job satisfaction is seen more in higher levels employees also. The turnover is increased with satisfied employees and satisfied sales force.
(C) 2014 www.ijip.in
July-September 2014
$110 \mid \mathrm{P}$ a g e 
The International Journal of Indian Psychology: Volume: 01 | Issue: 04 No. 2 | ISSN 2348-5396

Market conditions, job opportunities, length of work tenures, promotional policies along with satisfied sales force will increase sales.

Dissatisfied employees prefer the channels of exit or neutral productivity. They do not like to work hard or demonstrate their capacities. They continue to work as routine and uninterested persons. If they are pressurized to resort to unhealthy and disinterested jobs, they prefer to leave the job. Loyalty declines and criticism of the organization will suffer a lot.

Job design is created to help employees to get satisfaction and perform better. The job content, functions and relationship are well designed to motivate employees for better results and achievement of organizational goals.

\section{Organizational Commitment}

Organizational commitment is the emotional attachment people have toward the company they work for. A highly committed employee is one who accepts and believes in the company's values, is willing to put out effort to meet the company's goals, and has a strong desire to remain with the company. People who are committed to their company often refer to their company as "we" as opposed to "they" as in "in this company, we have great benefits." The way we refer to the company indicates the type of attachment and identification we have with the company.

Organizational commitment is one of those concepts that is used in a number of different ways. In most cases, we use the term to refer to a type of employee, that is, an employee with high organizational commitment. In this case, we generally refer to three observable patterns of behavior. When we see an employee exhibiting these patterns of behavior, we attribute these patterns to something we call commitment and we say that individual is committed. More recently, these behaviors have been termed organizational citizenship behaviors. The three components of commitment are:

Identification with the organization's goals and/or mission manifested in pride and defense of the organization. 
The International Journal of Indian Psychology: Volume: 01 | Issue: 04 No. 2 | ISSN 2348-5396

Long-term membership in the organization and intention to remain with the organization, often termed loyalty

High levels of extra role behavior, that is, behavior beyond required performance- Often referred to as citizenship behavior or pro-social behavior.

In the fields of Organizational Behavior and Organizational Psychology is, in a general sense, the employee's psychological attachment to the organization. It can be contrasted with other workrelated attitudes, such as job satisfaction, defined as an employee's feelings about their job, and organizational identification, defined as the degree to which an employee experiences a 'sense of onenesses with their organization.

Meyer and Allen (1994) state that organizational commitment is a "A psychological state that a) characterizes the employee's relationship with the organization, and b) has implications for the decision to continue membership in the organization". Other researchers user similar definitions that refer to an employee's attachment, goal congruency, identification, loyalty and allegiance to their organization.

Organizational commitment is important to researchers and organizations because of the desire to retain a strong workforce. Researchers and practitioners are keenly interested in understanding the factors that influence an individual's decision to stay or leave an organization. While turnover is related to all three types of commitment, research suggests there may be unique relationships between the three types of commitment and other work-related outcomes (e.g., absenteeism, organizational citizenship behaviors, and performance). Affective commitment tends to be most highly related to these outcomes. A review of the research suggests that researchers have typically focused on organizational outcomes and correlates of commitment. However, more recently, researchers are beginning to examine more individual-level correlates of affective commitment like stress, well-being and work-family conflict (Meyer et al., 2002). This shift in focus is relevant to the current work, as work-life programs are often instituted to positively affect these individual-level constructs. (Murphy \& Sauter, 2003). 
The International Journal of Indian Psychology: Volume: 01 | Issue: 04 No. 2 | ISSN 2348-5396

\section{METHOD}

\section{Hypothesis}

- There will be differences in the degree of job satisfaction and level of organizational commitment in the employees of private and public organization.

- There will be relationship between job satisfaction and organizational commitment in different organizations.

\section{Design}

There is a co relational field study in which job satisfaction and organizational commitment of engineers working in private and public organization have been investigated. The variables include in the present were organizational commitment which was in three parts affective commitment, continuance commitment and normative commitment; Job satisfaction (in five parts); work, officer, colleagues/friends, salary/wages and promotion

\section{Sample}

The present study was conducted on an incidental-purposive of 50 subjects: 25 engineers from private and 25 engineers from public organization. All the employees have been in the age range of 30 to 45 years with service experience ranges between 5 to 15 years and may be of both the services and working in government and private sectors.

\section{Tools}

Job Satisfaction- this variable was assessed on five aspects, viz., work itself, superiors, colleagues, pay and promotion. Summing up all the aspects gave the overall job satisfaction. It is based on Job Descriptive Index (Smith, Kendall and Hulin, 1969) adopted for Indian settings by Sayeed and Sinha (1981) and further translated in Hindi (by the standard two-time process) and successfully used on a sample other than industrial organizations (Sinha, 1993).

Organizational Commitment: Organization commitment scale developed by Puja Gupta, (2003), "Organization commitment type of Organization: A pilot study for Ph.D. work. (Adoption in Hindi, "Organization Commitment of Mowday, Steers and Poster, 1979). This questionnaire includes three dimensions and total no. of items is 15 . The types of three dimensions are Affective Commitment, Continuance Commitment and Normative Commitment. 
The International Journal of Indian Psychology: Volume: 01 | Issue: 04 No. 2 | ISSN 2348-5396

\section{RESULT AND DISCUSSION}

Table No. 1: Shows Mean, S.D. and 't' values of government and private engineers on organizational commitment.

\begin{tabular}{|c|c|c|c|c|c|}
\hline GROUPS & $\mathbf{N}$ & $\mathbf{M}$ & $\mathbf{S D}$ & $\mathbf{t}$ & $\mathbf{p}$ \\
\hline Govt. Eng. & 25 & 68.12 & 4.89 & & \\
\cline { 1 - 4 } Pvt. Eng. & 25 & 46.68 & 4.61 & $15.93 * *$ & 0.01 \\
\hline
\end{tabular}

$* * \mathrm{P}<0.01 \quad * \mathrm{P}<0.05$

The Table-1 reveals that the engineers in the government organization $(\mathrm{N}=25)$ has the mean score on organizational commitment variable is $\mathrm{M}=68.12$ with the standard deviation of $\mathrm{SD}=4.89 \&$ the engineers in the private organization $(\mathrm{N}=25)$ has the mean score $\mathrm{M}=46.68$ with the standard deviation of $\mathrm{SD}=4.61$. The $\mathrm{t}$-value of government \& private engineers on organizational commitment is $\mathrm{t}=15.93$ (significant at $0.01 \mathrm{Level}$ ), on this aspect the organizations seems to differ.

Table No. 2: Shows Mean, S.D. and 't' values of government and private engineers on job satisfaction.

\begin{tabular}{|c|c|c|c|c|c|}
\hline GROUPS & N & M & SD & t & p \\
\cline { 1 - 4 } Govt. Eng. & 25 & 64.24 & 6.17 & & \\
\cline { 1 - 3 } Pvt. Eng. & 25 & 64.52 & 5.59 & & N.S. \\
\hline
\end{tabular}

$* * \mathrm{P}<0.01 \quad * \mathrm{P}<0.05$

The table 2 reveals that the engineers in the government organization $(\mathrm{N}=25)$ has the mean score or job satisfaction is $\mathrm{M}=64.24$ with the $\mathrm{SD}=6.17$ \& the engineers in the private organization $(\mathrm{N}=25)$ has the mean score $\mathrm{M}=64.52$ with the $\mathrm{SD}=5.59$. The $\mathrm{t}$-value of government \& private
(C) 2014 www.ijip.in
July-September 2014
$114 \mid \mathrm{P}$ a g e 
The International Journal of Indian Psychology: Volume: 01 | Issue: 04 No. 2 | ISSN 2348-5396

engineers on job satisfaction is $\mathrm{t}=-.16$ which shows that three is not any significant difference on this aspect the organizations are not seem to differ.

Table No. 3: Correlation coefficient between Engineers of two organizations (Govt. and Pvt.) on organizational commitment (O.C.) and job satisfaction.

\begin{tabular}{|c|c|c|c|}
\hline Variables & N & r & Significance \\
\hline $\begin{array}{c}\text { Govn. and Pvt. Eng. } \\
\text { On O.C. }\end{array}$ & 50 & .08 & Non Sig. \\
\hline $\begin{array}{c}\text { Govn. and Pvt. Eng. } \\
\text { On Job Sat. }\end{array}$ & 50 & $.47^{*}$ & 0.05 \\
\hline
\end{tabular}

**Correlation is significant at the 0.01 level (2-tailed). ${ }^{*}$ Correlation is significant at the 0.05 level (2-tailed).

A careful inspection of inter correlation matrix (Table no. 3) reveals that the measures of organizational commitment of government and private engineers are statistically not significant. Results indicate that government and private organizations are significantly correlated with job satisfaction of engineers. The inter correlation between government engineers and private engineers on job satisfaction is .47 which is significant at 0.05 probability level.

Table No. 4 : Shows ANOVA values of organization commitment factors of government and private engineers

\begin{tabular}{|c|c|c|c|c|c|c|}
\hline Factors & Source & SS & df & MS & F & P \\
\hline \multirow{2}{*}{$\begin{array}{c}\text { Affective } \\
\text { O.C. }\end{array}$} & Between Groups & 800.00 & 1 & 800.00 & & \\
\cline { 2 - 6 } & Within Groups & 327.68 & 48 & 6.82 & & \\
\hline
\end{tabular}

(C) 2014 www.ijip.in

July-September 2014

115 | P a g e 
The International Journal of Indian Psychology: Volume: 01 | Issue: 04 No. 2 | ISSN 2348-5396

\begin{tabular}{|c|c|c|c|c|c|c|}
\hline \multirow{2}{*}{$\begin{array}{c}\text { Normative } \\
\text { O.C. }\end{array}$} & Between Groups & 380.88 & 1 & 380.88 & \multirow{2}{*}{64.68} & \multirow{2}{*}{.00} \\
\hline & Within Groups & 282.64 & 48 & 5.88 & & \\
\hline \multirow{2}{*}{$\begin{array}{c}\text { Continuance } \\
\text { O.C. }\end{array}$} & Between Groups & 816.08 & 1 & 816.08 & \multirow{2}{*}{124.49} & \multirow{2}{*}{.00} \\
\hline & Within Groups & 314.64 & 48 & 6.55 & & \\
\hline
\end{tabular}

The table 4 reveals that on Affective factor of engineers the $\mathrm{F}$ ratio $=117.18$ that is significant at .01 probability level which shows that there is significant difference on both groups of government and private engineers. On Normative factor of engineers the F ratio $=64.68$ that is significant at .01 probability level which shows that there is significant difference on both groups government and private engineers. On continuance factor of engineers the F ratio $=124.49$ that is significant at .01 probability level which shows that there is significant difference on both groups of government and private engineers. Bunker and Meena (2013), found significant difference between different medical employees in terms of their work environment, contentment and goal fulfillment as a organizational commitment and job satisfaction variable. The above research is supported by the present findings.

Table No. 5: Shows ANOVA values of job satisfaction factors of government and private engineers

\begin{tabular}{|c|c|c|c|c|c|c|}
\hline Factors & Source & SS & df & MS & F & p \\
\hline Work & $\begin{array}{c}\text { Between } \\
\text { Groups }\end{array}$ & 1.62 & 1 & 1.62 & .29 & .59 \\
\hline
\end{tabular}
(C) 2014 www.ijip.in
July-September 2014
$116 \mid \mathrm{P}$ a g e 
The International Journal of Indian Psychology: Volume: 01 | Issue: 04 No. 2 | ISSN 2348-5396

\begin{tabular}{|c|c|c|c|c|c|c|}
\hline & Within Groups & 264.00 & 48 & 5.50 & & \\
\hline \multirow{2}{*}{ Officer } & $\begin{array}{l}\text { Between } \\
\text { Groups }\end{array}$ & 7.22 & 1 & 7.22 & \multirow{2}{*}{5.95} & \multirow{2}{*}{.01} \\
\hline & Within Groups & 58.16 & 48 & 1.21 & & \\
\hline \multirow{2}{*}{ Friends } & $\begin{array}{l}\text { Between } \\
\text { Groups }\end{array}$ & 79.38 & 1 & 79.38 & \multirow{2}{*}{13.25} & \multirow{2}{*}{.00} \\
\hline & Within Groups & 287.44 & 48 & 5.98 & & \\
\hline \multirow{2}{*}{ Salary } & $\begin{array}{l}\text { Between } \\
\text { Groups }\end{array}$ & 13.52 & 1 & 13.52 & \multirow{2}{*}{15.10} & \multirow{2}{*}{.00} \\
\hline & Within Groups & 42.96 & 48 & .89 & & \\
\hline \multirow[t]{2}{*}{ Promotion } & $\begin{array}{c}\text { Between } \\
\text { Groups }\end{array}$ & & 1 & .08 & \multirow[t]{2}{*}{.02} & \multirow{2}{*}{.87} \\
\hline & Within Groups & 159.92 & 48 & 3.32 & & \\
\hline
\end{tabular}

The table 5 reveals that Engineers of government and private groups on work factors of job satisfaction have the $\mathrm{F}$ ratio $=.29$ that is no significant at .59 probability level which shows that there is not any significant difference on both groups of government and private engineers, On officer factor the $\mathrm{F}$ ratio $=5.95$ that is no significant at .01 probability level which shows that there is not any significant difference on both groups of government and private engineers. But on friends factor the engineers has $\mathrm{F}$ ratio $=13.25$ and on salary factors the $\mathrm{F}$ ratio $=15.10$ that is both significant at .01 probability level respectively which shows that there is significant difference on these two factors of job satisfaction between both groups of government and private engineers. On promotion factor the $\mathrm{F}$ ratio $=.02$ that is non significant .87 probability level which shows that there is not any significant difference on both groups of government and private engineers on this factor. 
The International Journal of Indian Psychology: Volume: 01 | Issue: 04 No. 2 | ISSN 2348-5396

\section{CONCLUSION}

The present investigation was conducted to find out the rate of organizational commitment and job satisfaction in relation to different organizations. After analyzing the results, it can be said that the hypothesis of the present investigation i.e., government and private organization differ from each other on job satisfaction and organizational commitment and the relationship between job satisfaction and organizational commitment is partially conformed. The findings of the present study lead to conclusions:

- That the quantitative differences in the two organizations regarding job satisfaction and organizational commitment dimensions are indicators of the typology of the organization;

- That the job satisfaction and organization commitment phenomena is recognized by all types of organizations but their perceptions differ with reference to their roles, quantification and manifestations;

- That people in different organizations differ in their perception of operational factors of commitment and job satisfaction in their organizations;

- The framework could be applied and tested not only on government or private organizations but on other types of organizations as well;

- Attempts should be made to use and apply the findings, wherever and whenever possible, for improvement and/or modification of organizational behaviour.

\section{REFERENCES}

1. Bunker, L. N. \& Meena, S., (2013). Employee's Mental Health and Organizational Commitment among technical and non-technical medical staff. Journal of Psychological Researchers, 57 (2), 5-12.

2. Meyer, J. P., Stanley, D. J., Herscivitch, L., \& Topolnytsky, L. (2002). Affective, continuance, and normative commitment to the organization: A meta-analysis of antecedents, correlates, and consequences. Journal of Vocational Behavior, 61, 20-52.

3. Mobey \& Locke, E. A. (1970), "Job Satisfaction and Performance: A Theoretical Analysis, Organizational Behavior and Human Performance", 5, pp. 484-500.

4. Mowday, R., Steers, R., and Porter, L. (1979). The measurement of organizational commitment. Journal of Vocational Behaviour, 14, 224-247. 
The International Journal of Indian Psychology: Volume: 01 | Issue: 04 No. 2 | ISSN 2348-5396

5. Murphy, L. R., \& Sauter, S. L. (2003). The USA perspective: Current issues and trends in the management of work stress. Australian Psychologist, 38, 151-157.

6. Sayeeed, O. B. \& Sinha, P. (1981). "quality of working life in relation to job satisfaction and performance in two organizations" Managerial Psychology, 2(1). 15-30.

7. Sinha, A. (1993). "Organizational Culture and Organizational Effectivness", A Report on the exploratory study at Lucknow: Secretariat, Dec.

8. Smith, P. C., Kendall, L.M., \& Hulin, C. L. (1969). Measurement of satisfaction in work and retirement. Chicago: Rand McNally. 